\title{
Developing College Student's Readiness to Build Family Well-Being Inventory for Effective Premarital Counseling
}

\author{
Nani M. Sugandhi \\ Universitas Pendidikan Indonesia \\ nani57@yahoo.com \\ Juntika Nurihsan \\ Universitas Pendidikan Indonesia \\ juntikanurihsan@upi.edu
}

\author{
Syamsu Yusuf LN, A \\ Universitas Pendidikan Indonesia
}

\begin{abstract}
The purpose of this study is to develop an inventory to measure the readiness of college students to build family well-being. In particular, this study produced an inventory tool based on the construct of student readiness to get married. Research uses research and development methods. The research procedures were carried out starting from construct development, expert weighing, face validation, to field trials to obtain empirical inventory validity and reliability. The standard research sample involved 267 students from six public and private universities in the city of Bandung. The results of the study obtained an inventory with a number of items declared valid and an adequate reliability score. The inventory developed was also accompanied by a usage manual which would later be used for premarital counseling. This study recommends the use of inventory as a basis for the development of effective premarital counseling for students in various universities.
\end{abstract}

Keywords: inventory, family well-being, college students, marriage counseling

\section{INTRODUCTION}

In the stages of development of human life, the age of students is the early adult phase, namely the age phase, which demands the existence and improvement of personal quality as a provision for living independently. Roles, duties and responsibilities are not only the achievement of academic success, but must be able to show behavior and individuals who adjust to social expectations as adults. One of the tasks in question is marriage and family life (Hurlock, 1991). Related to this task, students are expected to be able to complete their development tasks effectively, both in academic assignments, in preparing for careers, and in preparing for marriage.

However, the reality in the field is that there is a lot of anxiety in students related to marriage problems. The anxiety in question is because they do not have a prospective life partner and are still confused in choosing the criteria that are as expected. The results of the preliminary study revealed that the confusion was felt more by $45.54 \%$ of students when compared to the preparation of preparing a thesis which was considered not too confusing by $3.7 \%$ of students from 108 respondents in the 8th semester of the 4 UPI study programs.

The anxiety felt by students related to marriage needs to be followed up systematically and comprehensively to prevent the occurrence of unexpected things such as divorce. Data shows that there were 347,256 2015 divorce cases handled by the government, 90 percent of which were submitted by women and one third of the plaintiffs were aged 25-35 years (Kompas, 2016). One of the causes of this divorce includes the absence of mental readiness and lack of understanding of religion, especially the view of Islam in fostering a prosperous family.

Another finding from Kenedi (2005) states that students have not been able to act in accordance with positive considerations in preparing themselves for marriage, students have not fully realized, that accuracy, breadth and depth of knowledge and understanding of marriage issues is important for they are in arranging the self concept towards the expected marriage. In almost all universities there are a number of married students. There are those whose family lives are happy with the condition of all being well off, some are still mediocre and even lacking. Uniquely, some students who have built family life actually claim to be a quick driver of graduation with high grades, although some are the opposite.

The above phenomenon becomes an issue that needs attention. Systematic efforts through this model of premarital counseling need to be systematically arranged so that the continuity of a prosperous family life can be realized. There are a variety of premarital counseling approaches that are studied, but in this study there needs to be a new approach that promotes religion especially Islam in understanding marriage and various preparations for marriage. Therefore the pedagogic based Islamic prophetic counseling model is a new approach in premarital counseling. In the sense that counseling needs to prioritize the educational aspects based on the guidance of the Prophet Muhammad as an example of the best family in Islam. 
Based on the UPI research umbrella, this research is included in research for the development of education as UPI's identity. This research has an important contribution in supporting the achievements of RIP UPI, where the existence of the Islamic Prophetic Pedagogical Based Marriage Counseling Model is a form of concern for family welfare and development.

Based on the research background and to focus the research activities, the main formulation of this research problem was made, namely "how is the form of Islamic premarital pedagodic counseling model to improve the readiness of students to foster a prosperous family?" among others in year I: (1) How are the constructs of the concepts and scientific structures of premarital counseling based on Islamic prophetic pedagodics and family welfare along with academic studies that support the development of model devices ?; (2) How is the picture of students' readiness to foster a prosperous family in the city of Bandung ?; (3) What forms of premarital education already exist on campuses in the city of Bandung ?; (4) How is the form of premarital counseling based on Islamic prophetic pedagogics along with the tools to support the success of the program? Problem formulation for the second year: (1) what are the inputs from the results of expert and practitioner validation in the form of a focus group discussion onpremarital based Islamic prophetic pedagodics that has been adjusted to phase I research? (2) How is the implementation of a limited trial model of premarital counseling based on Islamic prophetic pedagodic? (3) How is the effectiveness of the implementation of the Limited Positive Parenting Program trial in the city of Bandung? The problem of the third year problem: (1) what are the inputs from the results of the effectiveness of the limited trial model of premarital counseling based on Islamic prophetic pedagodics that has been adjusted to phase II research? (2) How is the implementation of the results of the revised model of premarital counseling based on Islamic prophetic pedagodics in the city of Bandung?; (3) How is the effectiveness of the trial results of the revised model of premarital counseling based on Islamic prophetic pedagodics in the city of Bandung?

\section{The Concept of Premarital Counseling}

Premarital counseling is a service that provides assistance to students to understand and respond to the concept of marriage and family life based on the tasks of development and religious values as a reference in preparing for the marriage they expect. In line with this understanding, Lambeth (1993) suggests pre-marital counseling as a assistance service provided and has one distinct advantage, namely learning how to communicate and overcome problems before marriage, expressing things that can cause problems, and through learning efforts to open in terms of differences between potential partners .Associated with understanding as stated earlier, it can be concluded that premarital counseling can be widely accepted as a valuable idea. So this premarital counseling can be designed to help potential partners improve the skills needed to make marriages succeed.

The goals of premarital counseling are: (a) help couples develop skills to direct their way through marriage successfully; (b) identifying (and if possible addressing) areas of difference between pairs that might be the source of further conflict.

\section{Overview of Islamic Prophetic Pedagogics}

The word "prophetic" comes from English prophetical which has the meaning of Prophethood or the nature that is in a prophet. That is the nature of the prophet who has the character of a spiritually ideal individual, but also a pioneer of change, guiding the community toward improvement and carrying out endless struggles against oppression. In history, Prophet Ibrahim opposed King Namrud, Prophet Moses against Fir'awn, the Prophet Muhammad who guided the poor and young slaves against every oppression and injustice, had the aim of heading towards liberation. According to Shari'ati in Hilmy (2008: 179) the prophets did not only teach dzikir and prayer but they also came up with an ideology of liberation.

Definitively, prophetic education can be understood as a set of theories that not only describe and transform social phenomena, and not only change things for change, but more than that, it is expected to direct change on the basis of ethical and prophetic ideals. Kuntowijoyo himself admitted it, especially in the history of Islamization of Science as if it wanted to include something from the outside or completely reject existing knowledge (Kuntowijoyo in Roqib, 2011). Furthermore, Kuntowijoyo (in Roqib, 20112001: 357) incorporates a prophetic word into his findings about prophetic social sciences which contain three contents of social sciences namely humanism, liberation, and transcendence. Normativelyconceptually, the prophetic paradigm of Kuntowijoyo's version is based on verse 110 of Ali-Imran which means: You are the best people who are sent down / born in the midst of men to send to those who speak and prevent the evil and believe in Allah.

From this verse, the basis of the three pillars of the value of prophetic social science used by Kuntowijoyo is; 1) Amar Ma'ruf (humanization) contains the notion of humanizing humans. 2) Nahi Munkar (liberation) contains the notion of liberation. 3) Tu'minuna Blade (transcendence), the dimension of human faith (Rosidin, 2015).

While pedagogics is the science of education. Education in this case is Islamic education. Islamic education strives to build social capacity which implies that education must view humans as subjects of education. Therefore, starting point from the educational process it starts with the theologicalphilosophical understanding of humans, which in the end humans are introduced to the existence of themselves as God's khalifah on earth. Humanitarian education does not pretend to make human beings as a source of absolute value bonds (anthropocentric), because in medieval Europe, pure science and theistic 
technology made disaster in this modern century, where the human personality was divided into entanglement the dogma of materialism that obscures human values. Even though education is full of value and must be architectural or moral basis-transcendence.

\section{The Nature of Family Welfare}

Well-being has several terms, namely subjective well-being and psychological well-being. In this study, the intended welfare is subjive to positive well-being. Definition of subjective well-being Studies that examine the causes, predictors and consequences of happiness and satisfaction in life are associated with subjective well-being. Subjective well-being is an important aspect in developing a positive quality of life.

Happiness in subjective well-being is related to the level of emotions and how individuals understand the world and themselves. Whereas satisfaction in life is a broader understanding of the acceptance of individual life (Diener, 1985). According to some subjective well-being psychologists is a scientific term for happiness. Even Carr (2004) provides the same definition of happiness with subjective wellbeing,namely a positive psychological state characterized by high levels of satisfaction with life, high levels of positive emotions and low levels of negative emotions. The welfare referred to in this study is family welfare or family happiness.

\section{RESEARCH METHOD}

This is intended to implement a model-based pedagogical prefetik premarital counseling Islam. To make that happen, the method the research used is research and development (R \& D) from Borg and Gall (1989); while for the benefit of the design of research data collection and analysis for the benefit of model development, a qualitative quantitative mixed approaches approach was used from Cresswell (2003).

Based on the research methods, approaches, and designs chosen, the following procedures and research activities that will be passed in stages include: (1) conducting a descriptive analytical study of the constructs of the concepts and scientific structures of premarital counseling based on Islamic prophetic pedagogics along with academic studies that support implementation model; (2) tracking students' readiness in developing a prosperous family; (3) conducting searches for similar programs that already exist on campus in the city of Bandung; and (4) the form of premarital counseling based on Islamic prophetic pedagogics along with devices supporting the success of the program.

Research will be conducted on children and parents to do a survey of 5 campuses in Bandung which were randomly selected. The purpose of this survey is to find out the picture of students' readiness in developing a prosperous family. Based on the data obtained then the Islamic prophetic prophetic prophetic predagogical counseling model will be implemented in selected locations.
There is a number of data needed in this study. These data include: search results data from previous research and literature review both from journals, the internet and the latest relevant books both from within and outside the country; data on parenting and its impact on children. The first data, which is related to the need for strengthening academictheoretical studies from previous research results, is conducted using a desk study that is intensively carried out through and obtained from updated and trusted sources. The data in this study were captured through questionnaires, observations, and documentation studies. Distribution of questionnaires was conducted to capture the profile of attitudes and knowledge of parents and children in a multistage sampling. In-dept interviews are conducted to capture deeper information. While the documentation study was conducted to capture secondary data relating to the implementation of the parenting program.

\section{RESULTS AND DISCUSSION}

Conceptual Framework of Islamic Prophetic Pedagogical Based Marriage Counseling Model to Increase Student Readiness to Build Prosperous Families

Students are the age that is being confronted not only in achieving academic success, but also being able to show behavior and personality to explore various lifestyles and values, begin to be intellectually challenged, and start enjoying independence. In other words, the age of students as a phase of early adulthood is a period of adjustment to new life patterns and new social expectations as adults. Consequently students need to prepare themselves in the face of various challenges and difficulties in making adjustments independently and responsible for the new roles they have, including roles in facing marriage and family life both as husband, wife, parents and as members of the community.

Premarital counseling is a knowledge and skillbased training procedure that provides information about marriage that can be useful for maintaining and improving the relationship of married couples after they are married. Premarital counseling is also known as a marriage preparation program, premarital education, premarital educative counseling, and premarital therapy. Premarital counseling is given by a psychologist or marriage counselor.

Premarital counseling based on Islamic prophetic pedagogics is a pattern of giving assistance intended to help students understand and respond the concept of marriage and prosperous family life isbased on assignments developments and religious values obtained from the Prophet Muhammad as an internal reference preparing for the wedding that is expected. Core of service premarital counseling is counseling interviews, through interviews counseling it is expected that students can obtain knowledge, understanding, strong skills, values and beliefs help deal with problems that bother them towards the expected marriage. 
Premarital counseling based on Islamic prophetic pedagogics in question, designed in a system with components of Islamic education exemplified by the Prophet Muhammad with counseling aspects that are clearly identified and organized into one arrangement that can improve the effectiveness and efficiency of a service.

Ardimen (2000: 90) revealed the task of developing students in relation to marriage preparation, in the form of understanding the values of marriage and understanding the values of family life. Farozin (1996: 84-90) in his research found that there were several needs of early adulthood (students) in relation to married life and family, namely the need for guidance on the ins and outs of marriage, the need for premarital guidance, the need for explanations of marriage laws, the need for suggestions not to get married quickly.

Suwarjo (2000) in his research suggested the style of parenting and the identity status of marriage domains with intimacy status in Javanese ethnic students. This study found that parenting styles can influence the exploration of marriage domain identity and commitment activities that students have. The subject of this study was the Educational Sciences students of Yogyakarta State University.

\section{CONCLUSION}

A readiness to get married is very necessary with the aim that each partner can know, understand, and respond to the values of marriage which refers to the meaning and wisdom of marriage in family life. The meaning and wisdom of marriage in family life for those in the early adulthood phase, should be a provision of readiness to first recognize, understand, and react positively as a reference in building a harmonious and prosperous family life.

The characteristics of early adulthood that have a positive attitude towards marriage are presented as follows: (a) want to learn about the matter of marriage; (b) believe that marriage is the only way that legitimates sex between men and women; (c) believe that marriage is a sacred (sacred) religious teaching that must not be violated; and (d) want to prepare themselves for marriage.

The results of Kenedi's (2005) study that students have not been able to act in accordance with positive considerations in preparing themselves for marriage. Students have not fully realized, that the accuracy, breadth and depth of knowledge and understanding of marriage issues is important for them in arranging their self-concept towards the expected marriage. Concern, trust, emotional stability and optimism of students about the future of marriage is still low. Students have not been able to make a firm marriage commitment, which they can hold firmly as a principle, so that they are not independent and not confident. Their establishment is easily shaken and easily changes if they get pressure or influence from their environment and they are not able to plan for the future of their marriage properly.

Many factors have the potential to be a problem for students in arranging self-concepts towards the marriage they expect, including limited knowledge and understanding. This limited knowledge and understanding needs to be addressed through a model of premarital counseling based on Islamic prophetic pedagodics.

\section{REFERENCES}

[1] Ardimen. (2000). Implementation of Guidance and Counseling Services in Higher Education is associated with Student Needs . Thesis. Bandung: PPs UPI.

[2] Borg and Gall . ( 1989 ). Educational Research. New York: Pinancing.

[3] Creswell , John W. (2003). Research Design: Qualitative and Quantitative Approach. California: Sage Publication.

[4] Carr, A. (2004). Positive Psychology: The Science of Happiness and Human. Strengths. Hove \& NewYork: Brunner - Routledge Taylor \& Francis Group.

[5] Diener, E., Emmons, RA, Larsen, RJ, \& Griffin, S. (1985). The Satisfaction with Life Scale. Journal of Personality Assessment, 49 , 71-75.

[6] Farozin, M. (1996). Student Opinions and Needs About Academic Advisory Services at the IKIP Yogyakarta Faculty of Education. Thesis. Bandung: PPs IKIP.

[7] Hurlock, Elizabeth. (1991). Life Development Development Psychology. Erlangga: Jakarta.

[8] Compass. (2016). Young marriage, divorce even when I was young. Available online https://www.merdeka.com/khas/nikah-muda-cerai-punsaat-masih-belia-tren-perceraian-meningkat-3.html

[9] Kenedi, G. (2005. Self-Concept oriented Prenuptial Counseling Model. Dissertation at SPS UPI: Unpublished

[10] Roqib, M. (2011). Prophetic Education: Contextualization of Philosophy and Prophetic Culture in Education. Purwokerto: STAIN Press.

[11] Rosidin, D. (2015). Education in the Koran (Thematic and Semantic Studies). Bandung: Insan Rabbani.

[12] Rosidin, D. (2015). Revealing the Law Behind the Stories in the Koran. Bandung: Insan Rabbani.

[13] Suwarjo (2000). Relationship between Parenting Style and Marital Domain Identity Status with Intimacy Status in Javanese Ethnic Students (Study in Yogyakarta State University Students). Thesis. Bandung: PPs Unpad.

[14] Trull, Timothy. (2005). Clinical Psychology University of Missouri Columbia: USA. Winkel, WS 1991. Guidance and Counseling in Educational Institutions. Publisher: PT. Gramedia Widiasarana Indonesia. Jakarta. 